\title{
IMPLEMENTASI ELEARNING PADA MATA KULIAH FISIKA LINGKUNGAN UNTUK MENINGKATKAN KEMAMPUAN BERPIKIR KRITIS DAN KEMANDIRIAN BELAJAR MAHASISWA
}

\author{
Anita $^{1, a)}$, Eka Trisianawati ${ }^{2}$ \\ ${ }^{1,2}$ IKIP PGRI Pontianak, Jalan Ampera No.88, Pontianak 78116 \\ Email: a)anitaummufaqih@gmail.com
}

\begin{abstract}
Abstrak
Penelitian ini bertujuan untuk mengetahui bagaimana implementasi pembelajaran elearning terhadap kemampuan berpikir kritis dan kemandirian belajar pada mata kuliah fisika lingkungan. Penelitian ini merupakan jenis penelitian deskriptif. Subjek dalam penelitian ini adalah mahasiswa yang mengambil mata kuliah fisika lingkungan pada semester lima tahun ajaran 2015/2016 IKIP PGRI Pontianak. Teknik pengumpulan data yang digunakan dalam penelitian ini adalah teknik dokumentasi, komunikasi tak langsung, dan teknik pengukuran. Hasil penelitian diperoleh bahwa perencanaan Elearning berdasarkan APKG I tergolong sangat baik dengan nilai 3,25. Pelaksanaan Elearning berdasarkan APKG II tergolong sangat baik dengan nilai 3,40. Evaluasi Elearning berdasarkan APKG II tergolong angat baik dengan nilai 3,40. Kemampuan berpikir kritis mahasiswa tergolong rendah dengan rata-rata nilai 51,00. Sebanyak 11 mahasiswa memiliki kemampuan berpikir kritis rendah dari 18 mahasiswa. Kemandirian belajar mahasiswa tergolong baik dengan persentase jumlah jawaban positif $72,78 \%$ dan jawaban negatif $27,22 \%$
\end{abstract}

Kata-kata kunci : implementasi, fisika lingkungan, elearning, kemampuan berpikir kritis, kemandirian belajar

\begin{abstract}
This study aims to determine how the implementation of elearning learning to critical thinking skills and independent learning on environmental physics. This research is descriptive research. Subjects in this study were students in environmental physics at IKIP PGRI Pontianak in 2015/2016. The techniques used in this study is documentation techniques, indirect communication, and measurement techniques. The result showed that the planning Elearning based APKG I is in excellent condition with a value of 3.25. Implementation of eLearning based APKG II is in excellent condition with a value of 3.40. Elearning evaluation based APKG II classified angat well with the value of 3.40. Critical thinking ability of students is low with an average value of 51.00. A total of 11 students have the ability to think critically low of 18 students. Student learning independence quite well with the percentage of positive answers and negative answers $72.78 \% 27.22 \%$
\end{abstract}

Keywords: implementation, enviromental physics, e-learning, critical thiking skills, independent learning.

\section{Pendahuluan}

Elearning merupakan proses pembelajaran yang berbasiskan penggunaan sarana atau materi digital yang dalam pelaksanaannya terdapat interaksi online antara penggunanya dalam hal ini antara dosen mahasiswa ataupun diantara mahasiswa itu sendiri [6]. Pembelajaran berbasis Elearning merupakan salah satu strategi pembelajaran alternatif yang diharapkan mampu mengembangkan kemampuan penguasaan ilmu pengetahuan mahasiswa secara mandiri. Penerapan sistem elearning dirancang yang dapat berisi materi, tanya jawab, diskusi,refleksi, serta penugasan kepada mahasiswa. Elearning memberikan kesempatan yang lebih luas dan fleksibel kepada mahasiswa untuk mengembangkan potensinya 
sehingga tujuan pembelajaran dapat tercapai dengan baik. Sehingga kemandirian dalam belajar sangat dituntut dalam pembelajaran ini. Kemandirian dalam belajar merupakan sebuah usaha yang timbul dari dalam diri seseorang yang didasari oleh motivasinya sendiri untuk menguasai suatu materi tertentu sehingga dapat digunakan dalam menyelesaikan suatu permasalahan.

Selain itu, kemampuan yang harus dimiliki adalah kemampuan berpikir kritis. Sebab dalam Elearning segala informasi dapat termuat, sehingga masingmasing individu harus memiliki kemampuan untuk menyaring dan kritis terhadap informasi yang ada. Menurut paradigma konstruktivisme Piaget, salah satu kecakapan yang penting dimiliki oleh mahasiswa adalah kecakapan dalam mengatur dan mengontrol proses berpikirnya, antara lain kecakapan berpikir kritis, yaitu keterampilan individu menggunakan strategi berpikir dalam menganalitis argumen dan memberikan interpretasi berdasarkan persepsi yang benar dan rasional, analitis asumsi, dan bias dari argumen serta interpretasi logis [3]. Pola berpikir seperti ini termasuk ke dalam pola berpikir tingkat tinggi [1].

Berikir kritis adalah berpikir secara beralasan dan reaktif dengan menekankan pembuatan keputusan tentang apa yang harus dipercayai atau dilakukan. Kemampuan ini guna memberikan pengalaman untuk memahami dan mengklarifikasi data, mengumpulkan suatu informasi dan mengkombinasiknnya sehingga dapat menyimpulkan dan memberikan penilaian terhadap informasi tersebut [2].

Fisika lingkungan merupakan salah satu mata kuliah yang harus diambil oleh mahasiswa. Fisika lingkungan merupakan ilmu pengetahuan yang mendasari tentang gejala-gejala dalam alam semesta, termasuk di muka bumi sehingga terbentuk konsep dan prinsip.

Berdasarkan paparan di atas maka penelitian ini bertujuan untuk mengetahui implementasi elearning pada mata kuliah fisika lingkungan untuk meningkatkan kemampuan berpikir kritis dan kemandirian belajar mahasiswa

\section{Metode Penelitian}

Penelitian dilaksanakan di Institut Keguruan dan Ilmu Pendidikan (IKIP) PGRI Pontianak Kalimantan Barat. Metode penelitian yang digunakan dalam penelitian ini adalah penelitian deskriptif kualitatif. Penelitian deskriptif dimaksudkan untuk mengetahui gambaran umum tentang implementasi pembelajaran elearning yang dilihat dari perencanaan, pelaksnaan dan evaluasi pembelajaran elearning terhadap kemampuan perpikir kritis dan kemandirian belajar mahasiswa. Subjek dalam penelitian ini adalah mahasiswa yang mengambil mata kuliah fisika lingkungan pada semester lima tahun ajaran 2015/2016 IKIP PGRI Pontianak.

Teknik pengumpulan data yang digunakan dalam penelitian ini adalah teknik dokumentasi, observasi, angket, dan teknik pengukuran. Teknik dokumentasi digunakan untuk mengumpulkan berkas perencanaan yang dilakukan oleh seorang dosen sebelum melaksanakan proses belajar mengajar. Perencanaan tersebut berupa silabus dan SAP. Observasi dilakukan untuk mengamati kejadian pada saat pembelajaran berlangsung dan proses evaluasi yang dilakukan oleh dosen. Angket digunakan untuk memperoleh data kemandirian belajar mahasiswa. Sedangkan yang terakhir adalah teknik pengukuran digunakan untuk mengetahui kemampuan berikir mahasiswa yang dinilai dengan test. Instrument penelitian pada perencanaan digunakan lembar APKG 1, pelaksanaan pembelajaran dan proses evaluasi dinilai dari lembar APKG 2 dan Test kemampuan berpikir kritis.

Data yang diperoleh dalam penelitian yang akan dilakukan ini meliputi lembar observasi, data jawaban mahasiswa dalam menyelesaikan soal-soal tes yang diberikan dan angket mahasiswa. Adapun teknik analasis data yang digunakan dalam penelitian ini dideskripsikan.

Untuk mencari implementasi dosen dari mulai proses perencanaan, pelaksanaan dan proses evaluasi, lembar APKG I dan II, diberi skor mulai dari 1 hingga 4. Data kemudian dirata-ratakan dan dikategorikan sesuai dengan Tabel.1

Tabel 1. Kategori Perencanaan Pembelajaran

\begin{tabular}{|c|c|c|}
\hline Rata-rata Nilai & Nilai & Kategori \\
\hline $3,25-4,00$ & A & Sangat Baik \\
\hline $2,50-3,24$ & B & Baik \\
\hline $1,75-2,49$ & C & Kurang \\
\hline $0,00-1,74$ & D & Sangat Kurang \\
\hline
\end{tabular}

Untuk mencari kemampuan berpikir kritis, lembar jawaban mahasiswa dalam mengerjakan soal kemampuan berpikir kritis sebanyak 30 buah. Jika jawaban benar akan diberi skor 1 dan jika jawaban 
salah maka diberi skor 0. Jawaban kemudian dirataratakan. Mahasiswa dikatakan memiliki kemampuan berpikir kritis jika berada di atas rata-rata kelas. Sedangkan mahasiswa yang memiliki nilai di bawah rata-rata maka dikatakan belum memiliki kemampuan berpikir kritis.

Menjawab bagaimana profil kemandirian belajar mahasiswa, digunakan data yang berasal dari lembar jawaban mahasiswa berupa angket kemandirian belajar. Angket yang digunakan diukur dengan skala pengukuran Guttman. Jawaban berupa skor positif bernilai (1) dan skor negatif bernilai (0), berdasarkan Tabel.2

Tabel 2. Kategori Penilaian Skor Alternatif Jawavban

\begin{tabular}{|c|c|c|}
\hline \multirow{2}{*}{$\begin{array}{c}\text { Alternatif } \\
\text { Jawaban }\end{array}$} & \multicolumn{2}{|c|}{ Skor alternatif Jawaban } \\
\cline { 2 - 3 } & Positif & negatif \\
\hline Ya & 1 & 0 \\
\hline Tidak & 0 & 1 \\
\hline
\end{tabular}

\section{Hasil dan Pembahasan}

Penelitian ini bertujuan untuk mengetahui implementasi ELearning pada mata kuliah Fisika Lingkungan untuk meningkatkan kemampuan berfikir dan kemandirian belajar mahasiswa.Pengambilan data kemandirian belajar menggunakan angket dan kemampuan berpikir kritis menggunakan tes diambil pada mahasiswa semester III yaitu kelas A Pagi. Data penelitian yang diperoleh merupakan data primer berupa jawaban mahasiswa dalam menyelesaikan soal pada materi energi alternatif.

\section{Tabel 3. Rekapitulasi Data Kemampuan Mandiri Mahasiswa}

\begin{tabular}{|c|c|c|}
\hline Jumlah Data & $\begin{array}{c}\text { Jawaban } \\
\text { Positif }\end{array}$ & $\begin{array}{c}\text { Jawaban } \\
\text { Negatif }\end{array}$ \\
\hline 18 & 262 & 98 \\
\hline Rata-rata & 14,56 & 5,44 \\
\hline Persentase & $72,78 \%$ & $27,22 \%$ \\
\hline
\end{tabular}

Berdasarkan Tabel.3 diketahui bahwa persentase jumlah jawaban positif kemampuan mandiri mahasiswa sebesar $72,78 \%$ dan dan persentase jumlah jawaban negatif sebesar 27,22. Hal ini menunjukkan bahwa persentasejawaban positif kemampuan mandiri mahasiswa lebih banyak dibandingkan persentase jawaban negative.

\section{Tabel 4. Rekapitulasi Data kemampuan Berpikir Kritis Mahasiswa}

\begin{tabular}{|c|c|}
\hline Nilai Tertinggi & 63 \\
\hline Nilai Terendah & 33 \\
\hline Rata-rata & 51,00 \\
\hline Kategori Sedang & 9 \\
\hline Kategori Rendah & 11 \\
\hline
\end{tabular}

Berdasarkan Tabel.4, diketahui bahwa nilai ratarata kemampuan berfikir kritis mahasiswa sebesar 51,00 dengan nilai tertinggi 63 dan nilai terendah 33.Sebanyak 9 orang mahasiswa memiliki kemamapuan berpikir kritis tinggi dan 11 orang mahasiswa memiliki kemampuan berpikir kritis rendah.

Metode elearning dapat meningkatkan intensitas komunikasi interaktif dengan mahasiswa di luar kelas. Metode ini dapat memberikan keluwesan pada dosen dalam memberikan akses kepada mahasiswa untuk mendapatkan referensi ilmiah yang terkait proses pembelajaran

Aspek pengelolaan pembelajaran dalam elearning memiliki enam aspek, yaitu: aspek perencanaan pembelajaran, perancangan dan pembuatan materi, penyampaian pembelajaran, media dan interaktivitas pembelajaran, evaluasi pelaksanaan pembelajaran dan evaluasi model kesenjangan. Menurut kusumah, Elearning dapat memberikan beberapa keuntungan yaitu mahasiswa menjadi aktif, besemangat, menaikkan minat dan meningkatkan kesenganan dalam proses pembelajaran [7]

Berdasarkan hasil penelitian kategori pelaksanaan dan evaluasi pembelajaran (APKG 2) dengan rata-rata nilai 3,25 memiliki kategori sangat baik. Berarti dosen telah berupaya menjalankan proses pembelajaran sesuai dengan perencanaan yang telah dilakukan. Pembelajaran berbasis elearning merupakan salah satu strategi pembelajaran alternatif yang diharapkan mampu mengembangkan kemampuan penguasaan ilmu pengetahuan mahasiswa secara mandiri. Penerapan sistem elearning dirancang yang dapat berisi materi, tanya jawab, diskusi,refleksi, serta penugasan kepada mahasiswa. Elearning memberikan kesempatan yang lebih luas dan fleksibel kepada mahasiswa untuk mengembangkan potensinya sehingga tujuan pembelajaran dapat tercapai dengan 
baik.Sehingga kemandirian dalam belajar sangat dituntut dalam pembelajaran ini.

Berdasarkan hasil penelitian tentang kemandirian belajar dengan persentase $72,78 \%$. Hal ini berarti sebanyak $72,78 \%$ mahasiswa menjawab pertanyaan dengan kategori positif, dan hanya $27,22 \%$ yang menjawab pertanyaan dengan kategori negatif. Hal ini berarti mahasiswa telah memiliki kemandirian belajar yang baik.Pada dasarnya sebagian besar individu memiliki dan menerapkan kemandirian belajar dalam bidang akademik tertentu dan atau kegiatan hidup sehari-hari. Namun demikian belum tentu mereka melaksanakannya dengan baik. Satu sub-faktor penting dari keadaan individu yang mempengaruhi belajar adalah kemandirian belajar yaitu merancang tujuan, memilih strategi, dan memantau proses kognitif dan afektif yang berlangsung ketika seseorang menyelesaikan suatu tugas akademik.

Berdasarkan hasil penelitian kemampuan berpikir kritis mahasiswa tergolong rendah dengan kategori nilai rat-rata 51,00 dimana sebanyak 11 orang mahasiswa. Hal ini dikarenakan mahasiswa belum terbiasa mengerjakan soal yang memerlukan adanya pemecahan masalah. Kemampuan berpikir kritis merupakan kemampuan seseorang dalam menemukan dan mendefinisikan masalah, menyeleksi informasi untuk memecahkan masalah, mengenali asumsi dan interpretasi, merumuskan hipotesis, dan menarik kesimpulan. Berpikir kritis penting untuk dikembangkan karena merupakan potensi intelektual yang akan memberikan pengaruh bagi proses pembelajaran. Hal ini sejalan dengan pendapat Ennis, mendefinisikan berpikir kritis sebagai berpikir reflektif yang berfokus pada pola pengambilan keputusan tentang apa yang harus diyakini dan harus dilakukan. Berdasarkan definisi tersebut, maka menurut Ennis kemampuan berpikir kritis terdiri atas 12 komponen yaitu : (1) merumuskan masalah; (2) menganalitis argumen; (3) menanyakan dan menjawab pertanyaan; (4) menilai kredibilitas sumber informasi; (5) melakukan observasi dan menilai laporan hasil observasi; (6) membuat deduksi dan menilai deduksi; (7) membuat induksi dan menilai induksi; (8) mengevaluasi; (9) mendefinisikan dan menilai definisi; (10) mengidentifikasi asumsi; (11) memutuskan dan melaksanakan; (12) berinteraksi dengan orang lain [4].

Menurut Penner. kecakapan berpikir kritis merupakan salah satu modal dasar atau modal intelektual yang penting bagi setiap orang dan merupakan bagian fundamental dari kematangan manusia [1]. Oleh karena itu, pengembangan kemampuan berpikir kritis sangat penting bagi mahasiswa.Kecakapan berpikir kritis menggunakan dasar berpikir analisis argumen dan memunculkan wawasan terhadap tiap-tiap interpretasi untuk mengembangkan pola penalaran yang kohesif dan logis, kemampuan memahami asumsi, memformulasi masalah, melakukan deduksi dan induksi, serta mengambil keputusan yang tepat. ditambahkan Johnson, kecakapan berpikir kritis adalah potensi intelektual yang dapat dikembangkan melalui proses pembelajaran. Setiap manusia memiliki potensi untuk tumbuh dan berkembang menjadi pemikir yang kritis karena sesungguhnya kegiatan berpikir berhubungan dengan pengelolaan diri tiap manusia [5].

\section{Simpulan}

Berdasarkan hasil penelitian yang telah dilakukan, dapat ditarik kesimpulan sebagai berikut.Perencanaan Elearning berdasarkan APKG I tergolong sangat baik dengan nilai 3,25.Pelaksanaan Elearning berdasarkan APKG II tergolong sangat baik dengan nilai 3,40Evaluasi Elearning berdasarkan APKG II tergolong angat baik dengan nilai 3,40.Kemampuan berpikir kritis mahasiswa tergolong rendah dengan rata-rata nilai 51,00. Sebanyak 11 mahasiswa memiliki kemampuan berpikir kritis rendah dari 18 mahasiswaKemandirian belajar mahasiswa tergolong baik dengan persentase jumlah jawaban positif $72,78 \%$ dan jawaban negatif $27,22 \%$.

\section{Ucapan Terimakasih}

Terima kasih kami ucapkan kepada Lembaga Penelitian (LEMLIT) IKIP PGRI Pontianak karena penelitian ini merupakan bantuan yang didanai oleh APBS IKIP PGRI Pontianak tahun pendanaan 2015 dan kepada Prodi Pendidikan Fisika yang telah memfasilitasi kegiatan penelitian yang telah dilakukan ini

\section{Daftar Acuan}

\section{Jurnal}

[1] Liliasari.2002. Pengembangan Keterampilan Berpikir Kritis dan Kreatif untuk Meningkatkan Mutu Pendidikan Guru Kimia", Jurnal Penelitian Pendidikan, Vol.2 No.2 /Oktober 2002.

[2] Putra dan Sudiarti, 2015.Pengembangan Sistem E-Learning untuk Meningkatkan Keterampilan Berpikir Kritis Mahasiswa Pendidikan Fisika.JurnalFisikaIndonesia. No: 55 Vol XIX Edisi Mei 2015 ISSN : 1410-2994

\section{Buku}

[3] Presseisen, B. Z. 1985. Thinking Skill: Meaning and Model. Costa Al. ed. Developing Minds: A Resource Book for Theaching Thinking. Alexandria 
[4] Ennis, R. H. 1991. An Elaboration of Cardinal Goal of Science Instruction. Educational Phylosophy and Theory

[5] Nurhayati, Eti. 2011. Psikologi Pendidikan Inovatif. Yogyakarta. Penerbit: Pustaka Pelajar.

[6] Widuri, R. 2013. Pemanfaatan E-Learning dalam Pembelajaran Bahasa Indonesia.Tersedia :http://widuri.raharja.info/index.php?title=Pemb elajaran_E-learning. [Online 31 Agustus 2015]

[7] Kusumah, Y,S. 2006. Desain dan Pengembangan Courseware Berbasis Komputer dalam Implementasi E-Learning matematika Untuk Meningkatkan Pemahaman Matematika dan kemampuan Berpikir Kritis Siswa-siswa. Hibah Bersaing. DIKTI. Tersedia http://penelitian.lppm.upi.edu/detil/331/desaindan-pengembangan -courseware-berbasiskomputer-dalam-implementasi--e-learningmatematika -untuk-meningkatkan-pemahamanmatematik-dan-kemampuan-berfikir-kritissiswa-siswa[Online :21 Agustus 2015] 
